\title{
EVALUASI APLIKASI ST/SKI DI BPKP DKI JAKARTA DENGAN PENDEKATAN HOT-FIT MODEL
}

\author{
Nugroho Budi Sulistyanto \\ nugrohosulistyanto@gmail.com \\ Badan Pengawasan Keuangan dan Pembangunan \\ I Gede Agus Ariutama \\ Politeknik Keuangan Negara STAN
}

\begin{abstract}
To facilitate the preparation of Employee Performance Goals (SKP) and inputting documents as the basis of individual assessment, and to improve organizational performance, BPKP since 2014 has developed an application, ST or SKI, to assist employees in BPKP. However, it was only used by approximately $50 \%$ of BPKP representative offices in the Province. Thus, this study aims to determine the extent to which representative offices of BPKP implements ST or SKI and constraints using the HOT-Fit model framework. Qualitative descriptive approach with a case study strategy was employed in this study. Jakarta Representative Office of BPKP was chosen as the object of the study since it was one of the pioneers in the application implementation. The findings related to human and technology elements indicate that the application is functional,easy to use, and rarely experiences system failure. Yet, it is not integrated with other applications in BPKP. Whereas on the organization element, leaders at both central and representative levels provide attention and concern regarding its implementation. The ST or SKI in Jakarta Representative Office generally is in accordance with the HOT-Fit Model with several issues. These issues are associated with the accommodation of organizational interests, one of which is due to the absence of binding regulations.
\end{abstract}

Key words: application ST or SKI, HOT-Fit model, evaluation, information system

\begin{abstract}
ABSTRAK
Untuk memudahkan penyusunan Sasaran Kinerja Pegawai (SKP) dan input dokumen yang menjadi dasar penilaian atas kinerja individu pegawai, serta dalam rangka peningkatan kinerja organisasi melalui peningkatan prestasi kerja, BPKP sejak 2014 mengembangkan sebuah aplikasi Surat Tugas atau Sasaran Kinerja Individu (ST atau SKI) untuk memudahkan pegawai di lingkungan instansi BPKP. Akan tetapi, aplikasi tersebut hanya digunakan oleh kurang lebih 50\% kantor perwakilan BPKP di Provinsi. Penelitian ini bertujuan untuk mengetahui sejauh mana BPKP Perwakilan mengimplementasikan aplikasi ST atau SKI dan kendala yang dihadapi menggunakan framework HOT-Fit model. Pendekatan deskriptif kualitatif dengan strategi studi kasus diterapkan pada penelitian ini. Kantor Perwakilan BPKP DKI Jakarta dipilih sebagai obyek penelitian pada penelitian ini karena merupakan salah satu pionir penerapan aplikasi tersebut. Terkait dengan hasil penelitian pada elemen manusia dan teknologi, dapat disimpulkan aplikasi ini fungsional, jarang mengalami gangguan dan mudah digunakan oleh semua pegawai. Hanya saja aplikasi ini tidak terintegrasi dengan aplikasi lain di BPKP. Sedangkan pada elemen organisasi, pimpinan baik di level pusat maupun perwakilan memberikan perhatian dan kepedulian terkait implementasi aplikasi ini. Penerapan aplikasi ST atau SKI pada BPKP Perwakilan DKI Jakarta secara umum sesuai dengan HOT-Fit Model dengan beberapa kekurangan. Kekurangan tersebut terkait dengan akomodasi kepentingan organisasi yang salah satunya dikarenakan belum adanya peraturan yang mengikat.
\end{abstract}

Kata kunci: aplikasi ST atau SKI, HOT-Fit model, evaluasi, sistem informasi 


\section{PENDAHULUAN}

Sistem informasi memberikan keunggulan kompetitif bagi penggunanya sebagai pendukung dalam menjalankan pekerjaan sehari-hari. Salah satu keunggulan sistem informasi adalah dalam dimensi operasional, keunggulan yang berhubungan dengan transaksi dan proses sehari-hari (Laudon dan Laudon, 2001; McLeod dan Schell, 2011). Aplikasi merupakan bagian dari sistem informasi yang memiliki keunggulan pula bagi pemakainya. Dalam dunia perkantoran aplikasi diperlukan untuk mendukung kinerja dari pegawai (keunggulan pada dimensi operasional). Aplikasi tersebut dapat berfungsi sebagai tools yang dapat memudahkan kinerja pegawai, dengan kata lain mempermudah pekerjaan rutinitas sehingga pegawai tidak terlalu disibukkan dengan aktivitas yang bersifat administratif yang terlalu menyita banyak waktu. Untuk dapat sepenuhnya membantu atau mendukung pekerjaan pegawai, aplikasi tersebut haruslah disusun secara baik dan efektif sehingga keberadaan dan manfaatnya dapat dirasakan oleh pegawai yang bersangkutan. Evaluasi perlu dilakukan untuk mengukur seberapa baik dan efektif suatu aplikasi dalam kaitannya membantu pekerjaan pegawai. Evaluasi sendiri merupakan bagian dari siklus hidup suatu sistem (McLeod dan Schell, 2011). Evaluasi merupakan cara ilmiah (rasional, empiris, dan sistematis) dengan tujuan untuk mengetahui efektivitas dan efisiensi sebuah program (Sugiyono, 2015), sehingga proses evaluasi ini lebih mengarah pada usaha perbaikan yang perlu dilakukan oleh organisasi baik itu oleh swasta maupun pemerintah terhadap aplikasi yang dirasa memiliki manfaat yang kurang maksimal atau aplikasi yang belum dimanfaatkan secara maksimal.

Badan Pengawasan Keuangan dan Pembangunan (BPKP) merupakan salah satu lembaga pemerintah nonkementerian yang mempunyai tugas menyelenggarakan urusan pemerintahan di bidang pengawasan keuangan Negara atau daerah dan pembangunan nasional (www.bpkp.go.id). Dalam pelaksanaan tugas di bidang pengawasan keuangan dan pembangunan BPKP didukung oleh Sumber Daya Manusia (SDM) sebanyak 6.231 Pegawai Negeri Sipil (PNS). Sebanyak 6.231 PNS tersebut tersebar ke semua kantor BPKP Pusat maupun BPKP Perwakilan di seluruh Indonesia. Pegawai BPKP sebagaimana PNS yang lain, dalam rangka menyelenggarakan Pembinaan PNS diwajibkan menyusun Sasaran Kerja Pegawai (SKP) berdasarkan rencana kerja tahunan instansi yang ditetapkan setiap tahun pada bulan Januari. SKP yang telah disetujui dan ditetapkan oleh pejabat penilai tersebut akan menjadi dasar penilaian bagi pegawai yang bersangkutan. (Peraturan Pemerintah Nomor 46 Tahun 2011 tentang Penilaian Prestasi Kerja Pegawai Negeri Sipil).

Pada dasarnya penilaian prestasi kerja merupakan suatu proses rangkaian manajemen kinerja yang berawal dari penyusunan perencanaan prestasi kerja yang berupa Sasaran Kerja Pegawai (SKP), penetapan tolok ukur yang meliputi aspek kuantitas, kualitas, waktu, dan biaya dari setiap kegiatan tugas jabatan. Pelaksanaan penilaian SKP dilakukan dengan cara membandingkan antara realisasi kerja dengan target yang telah ditetapkan. Dalam melakukan penilaian dilakukan analisis terhadap hambatan pelaksanaan pekerjaan untuk mendapatkan umpan balik serta menyusun rekomendasi perbaikan dan menetapkan hasil penilaian. Untuk memperoleh objektivitas dalam penilaian prestasi kerja digunakan parameter penilaian berupa hasil kerja yang nyata dan terukur yang merupakan penjabaran dari visi, misi, dan tujuan organisasi, sehingga subjektivitas penilaian dapat diminimalisasi. Dengan demikian hanya PNS yang berprestasi yang mendapatkan nilai baik. Selain itu hasil rekomendasi penilaian prestasi kerja digunakan pula untuk peningkatan kinerja organisasi melalui peningkatan prestasi kerja, pengembangan potensi, dan karier PNS yang bersangkutan serta pengemba- 
ngan manajemen, organisasi, dan lingkungan kerja.

Untuk memudahkan pegawai menyusun SKP dan melakukan proses input dokumen-dokumen yang menjadi dasar penilaian atas kinerja individu pegawai, serta dalam rangka meningkatkan kinerja organisasi melalui peningkatan prestasi kerja, BPKP telah mengembangkan aplikasi untuk memudahkan pegawai di lingkungan instansi BPKP. Aplikasi yang dimaksud adalah aplikasi Surat Tugas atau Sasaran Kinerja Individu atau dapat disingkat aplikasi ST atau SKI. Aplikasi ini dapat diakses secara online lewat jaringan internet di alamat http://app.bpkp.go.id/ST/login. jsp. Aplikasi ini merupakan aplikasi yang dikembangkan sebagai peramban (browser) bagi aplikasi basis data penugasan para pegawai BPKP. Melalui aplikasi ini pengguna dapat menyusun SKP, membuat dan mencetak surat tugas, mengisi output pribadi, melakukan evaluasi laporan hasil kegiatan secara berjenjang, serta memudahkan pejabat penilai untuk memantau kegiatan masing-masing pegawai yang dinilai. Selain itu, aplikasi ini memudahkan unit kepegawaian untuk melakukan pendataan pegawai yang sudah maupun yang belum mengajukan SKP.

Aplikasi ST atau SKI ini telah diluncurkan sejak tahun 2014 dan sejak tahun tersebut sudah bisa digunakan untuk menyusun SKP dan menginput dokumendokumen pendukung dalam rangka penilaian prestasi kerja. Namun demikian berdasarkan hasil penelitian pendahuluan pada Pusat Informasi Pengawasan (Pusinfowas) BPKP yang mempunyai tugas mengembangkan dan memantau penggunaan aplikasi ini, penulis menemukan bahwa lebih dari 50\% kantor perwakilan BPKP di provinsi yang belum menggunakan fasilitas aplikasi ini dengan maksimal (kurang dari 100 input). Berdasarkan kondisi yang telah dijelaskan di atas maka evaluasi perlu dilakukan terhadap BPKP Perwakilan untuk mengetahui sejauh mana BPKP Perwakilan mengimplementasikan aplikasi ST atau SKI dan kendala yang dihadapi. Dengan berbagai pertimbangan di atas, penelitian terkait dengan evaluasi aplikasi ST atau SKI pada kantor BPKP perlu dilakukan. Strategi kualitatif studi kasus dipilih karena penulis ingin menyelidiki secara cermat suatu peristiwa, aktivitas atau proses. Penelitian studi kasus dilakukan dengan mengumpulkan informasi dengan menggunakan berbagai prosedur pengumpulan data berdasarkan waktu yang telah ditentukan (Creswell, 2015). Sedangkan BPKP Perwakilan DKI Jakarta dipilih dengan pertimbangan bahwa perwakilan ini merupakan salah satu pionir dalam penerapan aplikasi ini sejak tahun 2014 dan masuk sebagai lima besar BPKP Perwakilan dengan penggunaan aplikasi ST atau SKI tertinggi.

Framework evaluasi yang akan digunakan dalam penelitian ini adalah menggunakan Human Organization Technology-Fit Model atau yang dapat disingkat sebagai HOT-Fit Model. Model ini menempatkan komponen penting dalam sistem informasi, yaitu manusia (human), organisasi (organization), teknologi (technology) dan kesesuaian hubungan di antaranya Yusof et al. (2008). HOT-Fit Model dipilih karena model evaluasi ini dapat mengkolaborasikan antara pengaruh teknologi, manusia, dan organisasi secara pas (fit), dan merupakan model yang paling komprehensif dan holistic untuk melakukan evaluasi sistem informasi (Yusof, 2013). Dapat diambil kesimpulan bahwa penelitian ini bertujuan untuk mengetahui kesesuaian aplikasi ST atau SKI dengan framework HOT-fit Model serta mengetahui elemen mana dari tiga elemen penting framework HOT-Fit Model yaitu manusia, organisasi, dan teknologi yang masih membutuhkan perbaikan dalam pengimplementasian aplikasi ST atau SKI.

\section{TINJAUAN TEORETIS \\ Evaluasi Sistem Menggunakan HOT-Fit Model}

Arikunto dan Cepi (2008) mengemukakan bahwa evaluasi adalah kegiatan untuk mengumpulkan informasi tentang bekerja- 
nya sesuatu, yang selanjutnya informasi tersebut digunakan untuk menentukan alternatif yang tepat dalam mengambil sebuah keputusan. Fungsi utama evaluasi dalam hal ini adalah menyediakan informasi-informasi yang berguna bagi pihak decision maker untuk menentukan kebijakan yang akan diambil berdasarkan evaluasi yang telah dilakukan.

Yusof et al. (2008) dan Kusumawati dan Fanida (2014) menjelaskan bahwa model evaluasi HOT-Fit merupakan sebuah kerangka evaluasi yang dapat digunakan utuk melakukan evaluasi sistem informasi. Model ini menempatkan komponen penting dalam sistem informasi, yaitu manusia (human), organisasi (organization), teknologi (technology) dan kesesuaian hubungan di antaranya. Dari ketiga komponen tersebut, akan dikategorikan ke dalam dimensidimensi pengukuran. Terdapat delapan dimensi pengukuran yang diperoleh dari penggabungan antara model evaluasi sistem informasi dan teknologi informasi.

HOT-Fit Framework awalnya dikembangkan dari penggabungan IS Success Model (DeLone dan McLean, 2003) dan ITOrganization Fit Model yang dikenalkan oleh Scott-Morton (Yusof et al., 2006) sebagai kerangka untuk mengevaluasi Health Information System (HIS). IS Success Model digunakan untuk mengidentifikasi faktor, dimensi dan indikator pengukuran dalam hal kualitas sistem, kualitas informasi, kualtias pelayanan, penggunaan, kepuasan pengguna dan manfaat (Petter, DeLone, McLean, 2008), sedangkan IT-Organization Fit Model mengidentifikasi hubungan dan kesesuaian konsep diantara faktor manusia, teknologi dan organisasi.

Berikut adalah penjelasan mengenai tiga elemen penting dalam sistem informasi beserta delapan dimensi yang terdapat di dalam elemen tersebut:

\section{Manusia (human)}

Elemen manusia menilai sistem informasi dari sisi pengembangan sistem (system development) yang dilakukan tim IT ter- hadap sebuah aplikasi. Pengembangan yang dimaksud dimulai dari awal direncanakan, evaluasi yang dilakukan, hingga tujuan dari dibuatnya aplikasi. Penilaian kedua ada pada penggunaan sistem (system use) pada frekuensi dan luasnya fungsi dan penyelidikan sistem informasi. System use juga berhubungan dengan siapa yang menggunakan (who use it), tingkat penggunanya (level of user), pelatihan, pengetahuan, harapan dan sikap menerima (acceptance) atau menolak (resistance) sistem.

Komponen ini juga menilai sistem dari aspek kepuasan pengguna (user satisfaction) yaitu keseluruhan evaluasi dari pengalaman pengguna dalam menggunakan sistem informasi dan dampak potensial yang dirasakan dari penggunaan sistem informasi. Kepuasan pengguna dapat dihubungkan dengan persepsi manfaat dan sikap pengguna terhadap sistem informasi yang dipengaruhi oleh karakteristik personal.

\section{Organisasi (organization)}

Elemen Organisasi (organization) menilai sistem dari aspek struktur organisasi (structure) dan lingkungan organisasi (environment) tempat sistem teknologi informasi diimplementasikan. Struktur organisasi terdiri dari tipe, budaya, hirarki, perencanaan dan pengendalian sistem, strategi, manajemen dan komunikasi. Kepemimpinan, dukungan dari top manajemen dan dukungan staf merupakan bagian yang penting dalam mengukur keberhasilan sistem. Sedangkan lingkungan organisasi terdiri dari sumber pembiayaan, peraturan, politik, kompetisi, hubungan interorganisasional dan komunikasi.

\section{Teknologi (technology)}

Terdapat beberapa dimensi dalam elemen ini, yaitu:

Kualitas sistem (system quality).

Faktor ini digunakan untuk mengukur kualitas sistem teknologi informasi itu sendiri. Beberapa indikator yang pernah diteliti Yusof et al. (2006) dan Yusof et al. (2008) untuk mengukur nilai dari kualitas 
sistem adalah dengan melihat: indikator kemudahan yang meliputi mudah digunakan (ease of use) dan mudah dipelajari (ease of learning); indikator efisiensi yang meliputi lama respon (response time) dan lama loading; indikator kehandalan sistem yang meliputi terdapat bantuan teknis sistem (access to technical support), adanya peringatan kesalahan, fleksibel jika diintegrasikan dengan sistem lain (availability), teruji bebas dari eror (reliability) dan keamanan sistem (security); indikator kelengkapan meliputi fiturfitur yang lengkap, dan isi data-base yang lengkap.

Kualitas informasi (information quality).

Faktor ini digunakan untuk mengukur kualitas keluaran (output) dari sistem informasi. Beberapa indikator yang pernah diteliti Yusof et al. (2006) dan Yusof et al. (2008) untuk mengukur nilai dari kualitas informasi output adalah: Indikator isi (content) yang meliputi format sesuai kebutuhan, bentuk serta relevansi dari informasi yang dihasilkan, dan kelengkapan (completeness); Indikator kegunaan (usefulness) yang meliputi mudah dibaca, ringkas dan padat, dan informatif; dan Tingkat kehandalan data yang meliputi akurasi data, ketepatan waktu, dapat dibandingkan dan dapat diverifikasi.

Kualitas pelayanan (service quality).

Kualitas layanan berfokus pada keseluruhan dukungan yang diterima dari penyedia jasa layanan sistem. Kualitas layanan dapat dinilai dengan kecepatan respon, jaminan, empati, dukungan teknis dan tindak lanjut layanan kepada pengguna sistem.

Manfaat (net benefit)

Net benefit merupakan manfaat yang diperoleh dari penggunaan sistem. Net benefits dapat diukur dari manfaat sistem secara langsung (misalnya dari informasi yang dihasilkan sistem) maupun dari manfaat secara tidak langsung seperti dampak pada kinerja, efisiensi dan efektifitas kegiatan organisasi. Pada framework Hot-fit Model, kesesuaian antara ketiga elemen difokuskan pada kemampuan antara ele- men manusia, teknologi, dan organisasi untuk bisa saling menyesuaikan satu sama lain. Jadi, kesesuaian (fit) ini dapat diukur dan dianalisis dari beberapa kompatibilitas yang terlihat antara tiga elemen di atas (Yusof et al., 2008).

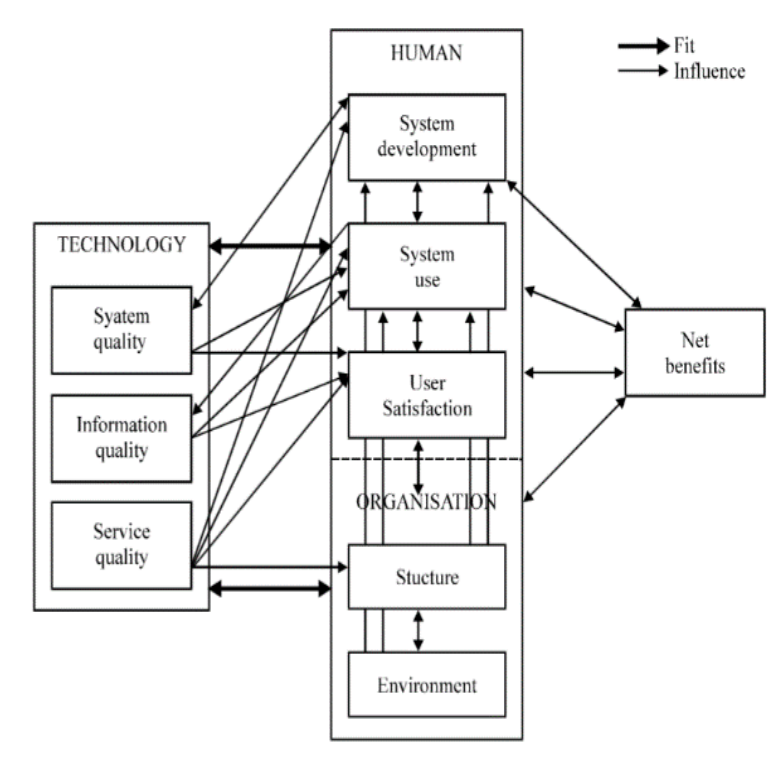

\section{Gambar 1}

HOT-Fit Evaluation Framework

Sumber: Yusof, 2011

\section{METODE PENELITIAN}

\section{Pendekatan dan Strategi Penelitian}

Penelitian ini menggunakan pendekatan deskriptif kualitatif. Metode penelitian kualitatif digunakan untuk mengivestigasi dan meneliti fenomena terkait hal yang terjadi, alasan dan bagaimana hal tersebut bisa terjadi (Chariri, 2009). Sehingga penelitian kualitatif berbasis pada kondisi obyek yang alamiah, dimana peneliti adalah sebagai instrumen kunci dan hasil penelitian kualitatif lebih menekankan makna daripada generalisasi. Sedangkan metode deskriptif adalah suatu metode dalam meneliti status sekelompok manusia, suatu objek, kondisi, sistem pemikiran ataupun peristiwa pada masa sekarang. Tipe penelitian ini berusaha menerangkan fenomena sosial tertentu (Sugiyono, 2010).

Strategi yang dilakukan pada penelitian ini adalah studi kasus yaitu dengan menyelidiki secara cermat suatu program, 
peristiwa, aktivitas atau proses pada suatu objek tertentu. Kasus-kasus dibatasi oleh waktu dan aktivitas (Creswell, 2015). Batasan aktivitas dilakukan dengan hanya meneliti pada BPKP Perwakilan Provinsi DKI Jakarta sebagai lokasi studi kasus pada tahun 2017.

\section{Jenis dan Sumber Data}

Penulis menggunakan data kualitatif berupa data primer dan data sekunder. Data primer merupakan data yang didapatkan oleh penulis secara langsung dari responden atau narasumber melalui wawancara dan kuesioner kepada pihakpihak terkait dengan tema penelitian. Kuesioner digunakan untuk memetakan permasalahan yang dihadapi oleh pengguna dan mengetahui tanggapan pengguna secara umum dan wawancara digunakan untuk memperoleh informasi yang belum didapatkan peneliti melalui studi literatur maupun analisis dokumen yang ada serta untuk menguatkan atau melakukan validasi atas informasi yang penulis peroleh dari kuesioner, studi kepustakaan, dan analisis dokumen. Sedangkan, data sekunder merupakan data atau informasi yang penulis peroleh dari hasil olah pihak lain atau diperoleh secara tidak langsung.

Narasumber yang diwawancarai dibagi menjadi tiga kelompok. Pertama, narasumber yang mempunyai kewenangan dalam mengembangkan aplikasi yaitu tim pengembang pada Pusat Informasi Pengawasan. Informasi yang ingin diperoleh pada narasumber ini adalah mengenai perencanaan pengembangan aplikasi dan tahapan dalam pengembangannya. Kedua, narasumber yang bertindak sebagai pengambil keputusan untuk memanfaatkan aplikasi yaitu penanggung jawab aplikasi pada Sub Bagian Kepegawaian dan Sub Bagian Program dan Pelaporan (Prolap) di BPKP Perwakilan DKI Jakarta. Narasumber yang telah diwawancarai adalah Kepala Sub Bagian Kepegawaian, Kepala Sub Bagian Prolap, dan dua orang admin aplikasi ST atau SKI di level BPKP Perwakilan Provinsi
DKI Jakarta. Informasi yang ingin didapatkan adalah terkait legal formal penggunaan aplikasi ST atau SKI dan strategi organisasi dalam penerapan aplikasi. Narasumber yang ketiga adalah enam user atau pengguna aplikasi di BPKP Perwakilan Provinsi DKI Jakarta. Informasi yang ingin didapatkan adalah terkait penggunaan aplikasi ST atau SKI secara langsung termasuk kendalakendala yang mungkin dihadapi.

\section{ANALISIS DAN PEMBAHASAN ST atau SKI Sebagai Sistem Informasi}

Seperti sudah dijelaskan pada tinjauan teoritis, pengertian sistem informasi adalah sekelompok elemen yang diintegrasikan untuk menjalankan suatu fungsi dan mencapai tujuan tertentu (Amarullah, 2016). Sistem terdiri dari beberapa komponen yang saling berhubungan dan bekerjasama untuk mengolah data menjadi informasi untuk mendukung pengambilan keputusan, koordinasi, pengawasan, analisa dan visualisasi dalam sebuah organisasi (Amarullah, 2016). Berdasarkan definisi di atas maka aplikasi ST atau SKI sudah memenuhi kriteria yang ada dalam pengertian tersebut. Hal ini dapat dilihat dari komponen dasar sistem informasi yang ada di dalam ST atau SKI. Komponen tersebut antara lain people, hardware, software, data, dan networks (Jogiyanto, 2005; O'Brien dan Marakas, 2009). Kelima komponen inilah yang membuat sebuah sistem informasi dapat menerima data masukan, mengolah data tersebut, kemudian menghasilkan informasi sebagai keluaran.

\section{People (Sumber Daya Manusia)}

Sumber Daya Manusia (SDM) dibutuhkan untuk mengoperasikan semua sistem informasi. Dalam sistem informasi secara umum SDM dibedakan menjadi dua macam yaitu SDM sebagai pemakai (user) dan SDM sebagai pakar sistem informasi (Amarullah, 2016).

Pemakai (user) adalah orang-orang yang menggunakan sistem informasi atau informasi yang dihasilkan oleh sistem 
tersebut. Pengguna akhir yang ada di dalam aplikasi ST atau SKI adalah semua pegawai BPKP yang berkewajiban menyusun SKP, atasan langsung pegawai yang bertugas melakukan penilaian, pegawai di bagian kepegawaian yang bertugas memantau hasil input SKP pegawai, dan pejabat di lingkungan instansi BPKP yang bertanggung jawab dalam pengambilan keputusan.

Pakar sistem informasi adalah orang yang mengembangkan dan mengoperasikan sistem informasi. Pengembang sistem informasi ini terdiri dari analis sistem, pembuat software, operator sistem, personal tingkat manajerial, teknisi dan staf administrasi sistem informasi lainnya. Analis sistem bertugas sebagai pendesain sistem berdasarkan kebutuhan informasi dari pemakai akhir.

Pembuat software bertugas membuat program komputer berdasarkan spesifikasi yang diperoleh dari analis sistem. Operator sistem bertugas untuk membantu mengawasi serta mengoperasikan sistem komputer dan jaringan dalam skala besar. Di BPKP level pusat semua pegawai yang menjalankan fungsi sebagai pakar sistem informasi berada dalam satu unit kerja yaitu Pusat Informasi dan Pengawasan (Pusinfowas). Sedangkan di level Perwakilan pegawai yang menjalankan fungsi sebagai pakar sistem berada dalam Sub Bagian Program dan Pelaporan (Prolap).

\section{Hardware}

Sumber daya perangkat keras tidak hanya meliputi komputer dan perlengkapan komputer lainnya, tapi juga termasuk semua media data seperti lembaran kertas, magnetic disk, dan optical disk. Sumber daya perangkat keras dalam sistem informasi berbasis komputer antara lain sistem komputer dan periferal komputer.

Sistem komputer terdiri dari unit pemrosesan pusat yang berisi pemrosesan mikro dan berbagai periferal yang saling berhubungan. Contoh yang paling berhubungan dengan aplikasi ini adalah laptop dan komputer. Semua unit kerja BPKP sudah memiliki baik komputer maupun laptop yang digunakan oleh pegawai dalam pelaksanaan tugas. Termasuk pegawai di BPKP Perwakilan Provinsi DKI Jakarta yang menggunakan komputer kantor, laptop kantor, maupun laptop pribadi untuk mengakses aplikasi ST atau SKI.

Periferal komputer terdiri dari peralatan seperti keyboard dan optical mouse yang digunakan untuk input data dan perintah, layar video dan printer untuk output informasi, dan magnetic atau optical disk untuk menyimpan data. Seperti halnya peralatan sistem komputer, peralatan periferal komputer seperti keyboard, optical mouse, layar video, printer, dan magnetic atau optical disk sudah tersedia di semua unit di BPKP dan digunakan untuk membantu pelaksanaan tugas setiap pegawai termasuk dalam mengoperasikan aplikasi ST atau SKI. Sedangkan untuk database dan server berada di lantai 7 kantor BPKP Pusat (masuk dalam tanggung jawab dan pengawasan Pusinfowas).

\section{Software}

Sumber daya perangkat lunak adalah subsistem perangkat lunak yang memungkinkan komputer untuk dijalankan. Sumber daya perangkat lunak dibedakan menjadi program dan prosedur. Program terdiri dari operating system (OS) dan aplikasi, khususnya aplikasi ST atau SKI. Komputer yang ada di BPKP umumnya menggunakan OS Windows. Selain ST atau SKI para user juga menggunakan beberapa aplikasi lain untuk membantu proses pelaporan dan penyusunan SKP, misalnya microsoft word dan microsoft excel.

\section{Data}

Sumber daya data adalah data yang disimpan, dihimpun, dan dientri untuk menghasilkan data yang baru. Dalam aplikasi ST atau SKI, data berupa input target SKP dibuat oleh setiap pegawai yang berkewajiban menysusn SKP, input bukti atas realisasi SKP dan pencetakan dokumen penilaian SKP oleh atasan langsung. 


\section{Network}

Sumber daya jaringan adalah jaringan yang digunakan untuk mendistribusikan atau memindahkan informasi dari satu pengguna ke pengguna lain. Aplikasi ST atau SKI merupakan aplikasi yang berbasis web yang dapat diakses menggunakan jaringan intranet BPKP maupun internet dari provider lain.

\section{Evaluasi Sistem Aplikasi ST atau SKI Melalui HOT-Fit Model}

Model ini menempatkan komponen penting dalam sistem informasi, yaitu manusia (human), organisasi (organization), teknologi (technology) dan kesesuaian hubungan di antaranya (Yusof, 2008). HOT-Fit Model dipilih karena model evaluasi ini dapat mengkolaborasikan antara pengaruh teknologi, manusia, dan organisasi secara pas (fit), dan merupakan model yang paling komprehensif dan holistic untuk melakukan evaluasi sistem informasi (Yusof, 2013). Kuesioner pada penelitian ini digunakan untuk memetakan permasalahan yang dihadapi oleh pengguna dan mengetahui tanggapan pengguna secara umum terhadap aplikasi ST atau SKI. Dari hasil kuesioner tersebut, secara garis besar dihitung persentase pendapat pengguna terkait aplikasi sehingga diketahui tanggapan pengguna secara umum. Kemudian, wawancara digunakan untuk menguatkan, dan memvalidasi informasi yang diperoleh peneliti serta memperoleh informasi yang belum didapatkan peneliti.

\section{Manusia}

Elemen manusia menilai sistem informasi dari sisi pengembangan sistem (system development) yang dilakukan tim IT terhadap sebuah aplikasi. Pengembangan yang dimaksud dimulai dari awal direncanakan, evaluasi yang dilakukan, hingga tujuan dari dibuatnya aplikasi. Penilaian kedua ada pada penggunaan sistem (system use) pada frekuensi dan luasnya fungsi dan penyelidikan sistem informasi. System use juga berhubungan dengan siapa yang meng- gunakan (who use it), tingkat penggunanya (level of user), pelatihan, pengetahuan, harapan dan sikap menerima (acceptance) atau menolak (resistance) sistem.

Komponen ini juga menilai sistem dari aspek kepuasan pengguna (user satisfaction) yaitu keseluruhan evaluasi dari pengalaman pengguna dalam menggunakan sistem informasi dan dampak potensial yang dirasakan dari penggunaan sistem informasi. Kepuasan pengguna dapat dihubungkan dengan persepsi manfaat dan sikap pengguna terhadap sistem informasi yang dipengaruhi oleh karakteristik personal.

\section{Pengembangan sistem (system develop- ment)}

Penilaian terhadap dimensi pengembangan sistem berkaitan dengan pengembangan yang dilakukan tim IT terhadap aplikasi ST atau SKI. Pengembangan dimaksud dimulai dari awal direncanakan, evaluasi yang dilakukan, hingga tujuan dari dibuatnya aplikasi ini. Awal mula pengembangan aplikasi ST atau SKI adalah berdasarkan permintaan Sekretaris Utama (Sesma) BPKP sebagai perwujudan PP Nomor 46 Tahun 2011 tentang Penilaian Prestasi Kerja Pegawai Negeri Sipil, pada tahun 2013. Tugas pembuatan aplikasi ST atau SKI diserahkan kepada Sub Bidang Pengembangan Sistem Aplikasi, Bidang Pengembangan Sistem Informasi pada unit Pusinfowas BPKP. Seiring berjalannya waktu sambil merancang dan menyempurnakan aplikasi, tim pengembang aplikasi terus berinteraksi dengan Sesma untuk mengakomodasi kebutuhan dan menuangkannya dalam rancangan desain aplikasi.

Implementasi aplikasi ST atau SKI telah direncanakan dengan baik oleh manajemen. Mulai dari pengembangan, implementasi, kemudian sosialisasi. Pengembangan dilakukan secara internal di Pusinfowas, terdiri dari beberapa tim, diantaranya tim yang mengembangkan aplikasi, tim yang mengembangkan database aplikasi, dan tim yang mengembangkan di sisi server dan jaringan. Kemudian secara implementasi, 
aplikasi ST atau SKI dilakukan secara bertahap mulai dari internal Pusinfo sebagai awal uji coba, beberapa BPKP Perwakilan sebagai pionir, hingga seluruh BPKP Perwakilan.

\section{Penggunaan sistem (system use)}

Penilaian kedua ada pada penggunaan sistem (system use) pada frekuensi dan luasnya fungsi dan penyelidikan sistem informasi. System use juga berhubungan dengan siapa yang menggunakan (who use it), tingkat penggunanya (level of user), pelatihan, pengetahuan, harapan dan sikap menerima (acceptance) atau menolak (resistance) sistem.

Aplikasi ST atau SKI digunakan oleh seluruh pegawai yang berstatus PNS pada instansi BPKP. Pelatihan penggunaan aplikasi ST atau SKI dilakukan secara bertahap. Pusinfowas sebagai unit yang ditugaskan mengembangkan aplikasi memanggil perwakilan dari masing-masing BPKP Perwakilan untuk dilakukan pelatihan dan sosialisasi atas aplikasi ST atau SKI. Selanjutnya, perwakilan dari masing-masing BPKP Perwakilan tersebut melakukan sosialisasi pada Perwakilannya masingmasing.

Tim pengembang dari aplikasi ST atau SKI menyatakan bahwa desain atau tampilan user interface dari aplikasi ini tergolong mudah difahami karena mempunyai konsep yang sama dengan tampilan aplikasi komputer pada umumnya. Hal ini berpengaruh pada pengetahuan atau keterampilan pengguna dalam menggunakan perangkat komputer. Pengguna tidak perlu harus mahir dalam menggunakan komputer untuk menggunakan aplikasi ini. Hal ini didukung dengan pernyataan pengguna atau user bahwa 97\% responden menyatakan aplikasi ST atau SKI mudah digunakan.

Semua responden menginginkan aplikasi ST atau SKI tetap dipertahankan namun dengan beberapa catatan. Mereka menginginkan ada tambahan fitur agar manfaat aplikasi ST atau SKI lebih bisa dirasakan oleh pegawai. Sebanyak 90\% responden termasuk Kepala Sub Bagian Kepegawaian menginginkan aplikasi ST atau SKI selain memfasilitasi dalam penyusunan SKP juga memfasilitasi pegawai dalam menyusun angka kredit yang memang diwajibkan bagi jabatan fungsional setiap enam bulan sekali. Hal ini mengingat faktor penentu angka kredit utama adalah surat tugas beserta output dari surat tugas tersebut dimana hal ini telah ada dalam aplikasi ST atau SKI. Selain itu salah satu responden menginginkan ada tambahan yang lebih spesifik lagi berkaitan dengan pembuatan surat tugas. Hal yang paling sering bersinggungan dengan pegawai terkait aplikasi ini adalah pembuatan surat tugas. Surat tugas tidak dapat berdiri sendiri karena perlu dilengkapi dengan surat pengantar, rencana waktu kegiatan, dan rencana biaya kalau ada. Kelengkapankelengkapan tersebut secara format belum bisa dicetak langsung dari aplikasi.

\section{Kepuasan pengguna (user satisfaction)}

Kepuasan pengguna dapat didefinisikan sebagai keseluruhan evaluasi dari pengalaman pengguna dalam menggunakan sistem informasi dan dampak potensial yang dirasakan dari penggunaan sistem informasi. Kepuasan pengguna dapat dihubungkan dengan persepsi manfaat dan sikap pengguna terhadap sistem informasi yang dipengaruhi oleh karakteristik personal.

Kepuasan pengguna dilihat dari apakah informasi yang dihasilkan oleh ST atau SKI bisa membantu pekerjaan mereka dan apakah pengguna merasa puas dengan informasi yang dihasilkan oleh aplikasi ini. Berdasarkan jawaban dari responden terkait kepuasan dalam menggunakan aplikasi ST atau SKI, 67,5\% responden menyatakan puas terhadap fasilitas dan fitur yang ada pada aplikasi ST atau SKI. Namun $80 \%$ dari responden yang sama menyatakan bahwa perlu adanya pengembangan pada aplikasi ini agar lebih sempurna. Lebih spesifik lagi responden puas dengan keberadaan aplikasi ini karena dapat lebih efisien mem- 
bantu dalam penyusunan SKP dan surat tugas sehari-hari yang sebelumnya masih disusun secara manual.

Salah satu hal yang dikeluhkan pengguna adalah paperless sebagai salah satu manfaat tambahan dari aplikasi ST atau SKI belum dapat dijalankan secara maksimal. Aplikasi ini memungkinkan pengguna melakukan input konsep surat tugas secara digital kemudian atasan dapat melakukan perbaikan atas konsep surat tugas tersebut secara digital pula. Namun pada prakteknya kebiasaan lama yang harus mencetak surat tugas secara fisik masih belum bisa ditinggalkan. Hal ini disebabkan karena beberapa Pengendali Teknis (Dalnis) dan Pengendali Mutu (Daltu) yang sudah termasuk senior tidak terbiasa melakukan koreksi pada surat dalam format digital. Salah satu sebabnya adalah karena faktor usia yang tidak terlalu kuat berlama-lama di depan layar komputer. Hal sama terjadi ketika mengunggah output dari surat tugas misalnya berupa laporan.

\section{Tabel 1}

Resume Elemen Manusia dari Evaluasi ST atau SKI

\begin{tabular}{ll}
\hline \multicolumn{1}{c}{ Dimensi } & \multicolumn{1}{c}{ Temuan } \\
\hline Pengembangan & $\begin{array}{l}\text { Pengembangan merupakan } \\
\text { instruksi dari pusat. Adanya } \\
\text { pembagian tim dalam pe- } \\
\text { ngembangan aplikasi. }\end{array}$ \\
& $\begin{array}{l}\text { Implementasi dilakukan se- } \\
\text { cara bertahap. }\end{array}$ \\
\hline Penggunaan & ST atau SKI digunakan oleh \\
Sistem & seluruh pegawai yang ber- \\
& status PNS pada instansi \\
& BPKP. Pelatihan ST atau SKI \\
& dilakukan secara bertahap. \\
& Tidak harus mahir komputer \\
& untuk menggunakan apli- \\
& kasi ST atau SKI. User meng- \\
& inginkan ST atau SKI tetap \\
dipertahankan. Sebagian & besar user menginginkan ada \\
& tambahan manfaat dari ST \\
& atau SKI. \\
\hline Kepuasan & Sebanyak 67,5\% responden \\
\hline
\end{tabular}

\begin{tabular}{ll}
\hline Pengguna & puas terhadap fasilitas dan \\
& fitur yang ada pada ST atau \\
& SKI. Aplikasi ST atau SKI \\
& lebih efisien dalam mem- \\
& bantu pekerjaan. Fungsi \\
& paperless belum maksimal.
\end{tabular}

Sumber: data yang diolah peneliti

\section{Organisasi}

Elemen Organisasi (organization) menilai sistem dari aspek struktur organisasi (structure) dan lingkungan organisasi (environment) tempat sistem teknologi informasi diimplementasikan. Struktur organisasi terdiri dari tipe, budaya, hirarki, perencanaan dan pengendalian sistem, strategi, manajemen dan komunikasi. Kepemimpinan, dukungan dari top manajemen dan dukungan staf merupakan bagian yang penting dalam mengukur keberhasilan sistem. Sedangkan lingkungan organisasi terdiri dari sumber pembiayaan, pemerintahan, politik, kompetisi, hubungan interorganisasional dan komunikasi.

\section{Struktur organisasi (structure)}

Penilaian terhadap dimensi struktur organisasi terdiri dari tipe, budaya, hirarki, perencanaan dan pengendalian sistem, strategi, manajemen dan komunikasi. Kepemimpinan, dukungan dari top manajemen dan dukungan staf merupakan bagian yang penting dalam mengukur keberhasilan sistem.

BPKP Perwakilan DKI Jakarta merupakan instansi pemerintah yang dipimpin oleh seorang Kepala Perwakilan. Kepala Perwakilan membawahi beberapa Kepala Bidang (Kabid) atau Kepala Bagian (Kabag) dan Kabid membawahi pegawai-pegawai pada bidang masing-masing. Berdasarkan struktur organisasi dari BPKP Perwakilan DKI Jakarta, dapat dilihat bahwa tugas dan perintah dikomunikasikan secara hierarki dari atasan kepada bawahan. Berkaitan dengan implementasi aplikasi ST/SKI, perintah penggunaan berasal dari Sesma BPKP kepada seluruh Kepala Perwakilan. Kepala Perwakilan kemudian meneruskan 
perintah tersebut kepada Kabid atau Kabag yang bersangkutan. Pada BPKP Perwakilan Provinsi DKI Jakarta aplikasi ST atau SKI merupakan tanggung jawab dari Kepala Bagian Umum, lebih spesifik lagi adalah tanggung jawab dari Sub Bagian Program dan Pelaporan (Prolap).

Pada BPKP Perwakilan Provinsi DKI Jakarta, Kepala Perwakilan sangat mendukung adanya aplikasi ini. Berdasarkan informasi dari responden Kepala Perwakilan tidak akan mau menandatangani dokumen yang seharusnya dicetak menggunakan aplikasi namun tidak dilakukan. Hal ini adalah bentuk komitmen agar seluruh pegawai tertib menggunakan aplikasi ST atau SKI. Kepala Perwakilan juga mendapat dukungan dari stafnya. Dukungan tersebut datang dari Kepala Sub Bagian Prolap sebagai penanggung jawab aplikasi ST atau SKI secara langsung. Kasubag Prolap sering menghimbau kepada seluruh pegawai untuk tertib menggunakan aplikasi ini pada rapat staf bersama Kepala Perwakilan. Rapat staf merupakan bentuk komunikasi antara Kepala Perwakilan dengan seluruh staf pejabat struktural di lingkungan BPKP Perwakilan Provinsi DKI Jakarta. Sedangkan komunikasi antara Kasubag Prolap sebagai penanggung jawab aplikasi dengan seluruh pengguna pada setiap Bidang adalah berupa laporan secara lisan dari setiap pegawai yang akan melakukan input surat tugas kepada Kasubag Prolap. Berdasarkan informasi dari responden, laporan ini bersifat wajib agar Kasubag Prolap dapat mengetahui PKPT atau non PKPT mana yang akan dieksekusi oleh pegawai yang bersangkutan.

BPKP Pusat belum menerapkan sistem reward and punishment atas penggunaan aplikasi ini. Aplikasi yang dimiliki oleh BPKP yang lain misalnya Document Management System (DMS) sudah menerapkan sistem ini dengan BPKP Perwakilan DKI Jakarta adalah yang terbaik pada tahun 2015. DMS digunakan untuk mengelola dokumen digital yang ada di BPKP sebagai bagian dari sharing knowledge, media dokumentasi, dan media penyampaian laporan antar unit kerja. Belum adanya sistem reward and punishment menyebabkan tidak ada motivasi untuk menggunakan aplikasi ST atau SKI secara tertib dan maksimal. Hal ini dikonfirmasi oleh salah satu responden yang mengatakan bahwa sebenarnya tidak ada efek apa-apa meskipun pegawai tidak menggunakan aplikasi ST atau SKI.

Pada level BPKP Pusat, pada bulan Januari awal tahun 2015 Sesma telah mengirimkan surat edaran kepada seluruh BPKP Perwakilan agar menggunakan aplikasi ST atau SKI untuk melaporkan capaian SKP tahun 2015 dan menyusun target SKP tahun 2016. Hal ini menunjukkan bahwa secara struktur, organisasi peduli dan menaruh perhatian terhadap aplikasi ini namun karena masih sebatas himbauan dan belum adanya sanksi tegas menyebabkan tertib dalam menggunakan aplikasi masih belum maksimal. Belum maksimalnya penggunaan aplikasi ST atau SKI salah satu contohnya adalah sering terlambat melakukan upload atas output surat tugas.

\section{Lingkungan organisasi (environment)}

Lingkungan organisasi dapat didefinisikan sebagai hal-hal yang berada di luar organisasi namun masih memiliki dampak pada implementasi sistem informasi, dalam hal ini aplikasi ST atau SKI. Lingkungan organisasi berkaitan pula dengan lingkungan dimana aplikasi ST atau SKI dikembangkan. Penilaian atas lingkungan organisasi terdiri dari sumber pembiayaan, peraturan, politik, kompetisi, hubungan interorganisasional dan komunikasi.

Aplikasi ST atau SKI sebagaimana aplikasi-aplikasi lain yang dimiliki BPKP dibebankan pada anggaran Sub Bidang Pengembangan Sistem Aplikasi yang berada di bawah Bidang Pengembangan Sistem Informasi, Pusinfowas BPKP. ST atau SKI dikembangkan berdasarkan amanat dari PP Nomor 46 Tahun 2011 tentang Penilaian Prestasi Kerja Pegawai Negeri Sipil. Selain dari PP Nomor 46 tahun 2011 di atas 
aplikasi ST atau SKI juga dilaksanakan sesuai dengan Peraturan Kepala BKN Nomor 1 Tahun 2013 tentang Ketentuan Pelaksanaan Peraturan Pemerintah Nomor 46 Tahun 2011 tentang Penilaian Prestasi Kerja Pegawai Negeri Sipil. Perka BKN Nomor 1 Tahun 2013 ini adalah sebagai petunjuk pelaksanaan dari PP Nomor 46 Tahun 2011.

Dalam PP tersebut disebutkan bahwa setiap PNS wajib menyusun SKP sebagaimana dimaksud berdasarkan rencana kerja tahunan instansi yang memuat kegiatan tugas jabatan dan target yang harus dicapai dalam kurun waktu penilaian yang bersifat nyata dan dapat diukur. Dalam PP tidak disebutkan harus menggunakan aplikasi dalam penyusunannya. Namun demikian tujuan aplikasi adalah untuk membantu otomatisasi pekerjaan yang sebelumnya dilakukan secara manual menjadi tersistem dalam aplikasi.

Komunikasi yang bagus antar pegawai di dalam organisasi berdampak pula pada pemakaian aplikasi ST atau SKI. Komunikasi yang terjadi tidak hanya antar pegawai yang memiliki umur sepantaran namun juga antara pegawai senior dan pegawai yang lebih muda. Beberapa responden mengatakan bahwa pegawai senior tidak terbiasa dengan aplikasi komputer. Untuk mengatasi masalah ini terkadang pegawai senior tersebut meminta bantuan kepada pegawai yang lebih muda. Tidak menutup kemungkinan pula ada pegawai muda yang masih belum paham dalam penggunaan aplikasi. Daripada meminta bantuan dari Pusinfowas BPKP salah satu responden menyatakan lebih memilih bertanya pada pegawai lain yang lebih paham.

\section{Tabel 2}

\section{Resume Elemen Organisasi dari Evaluasi} ST/SKI

\begin{tabular}{ll}
\hline Dimensi & Temuan \\
\hline Struktur & $\begin{array}{l}\text { Adanya dukungan dari top } \\
\text { manajemen. Adanya kepeduli- } \\
\text { an organisasi pusat maupun }\end{array}$ \\
\hline
\end{tabular}

perwakilan. Telah sering dilakukan himbauan menggunakan ST atau SKI. Belum diterapkan sistem reward and punishment dari organisasi.

Lingkungan Adanya anggaran pengembangan aplikasi. Aplikasi ST atau SKI dibuat mengikuti peraturan. Adanya Komunikasi yang bagus antar pegawai.

Sumber: data yang diolah peneliti

\section{Teknologi}

Pada elemen teknologi dapat dijabarkan kedalam tiga dimensi, yaitu kualitas sistem, kualitas informasi, dan kualitas pelayanan.

\section{Kualitas sistem (system quality).}

Faktor ini digunakan untuk mengukur kualitas sistem teknologi informasi itu sendiri. Beberapa indikator yang pernah diteliti Yusof et al. (2006) dan Yusof et al. (2008) untuk mengukur nilai dari kualitas sistem adalah sebagai berikut: 1) indikator kemudahan yang meliputi mudah digunakan (ease of use) dan mudah dipelajari (ease of learning), 2) indikator efisiensi yang meliputi lama respon (response time) dan lama loading, 3) indikator kehandalan sistem yang meliputi terdapat bantuan teknis sistem (access to technical support), adanya peringatan kesalahan, fleksibel jika diintegrasikan dengan sistem lain (availability), teruji bebas dari eror (reliability) dan keamanan sistem (security), 4) indikator kelengkapan meliputi fitur-fitur yang lengkap, dan isi data-base yang lengkap.

Tim pengembang aplikasi menyatakan bahwa aplikasi ST atau SKI menggunakan desain antarmuka (user interface) yang disesuaikan dengan tampilan website pada umumnya. Hal ini didukung dengan keterangan $95 \%$ responden yang menyatakan bahwa aplikasi ST atau SKI mudah digunakan. Petugas admin pada BPKP Perwakilan Provinsi DKI Jakartapun menyatakan bahwa aplikasi ST atau SKI termasuk aplikasi yang simpel. Selain itu petugas admin juga 
menyatakan bahwa aplikasi ST atau SKI mudah dipelajari karena disertakan petunjuk penggunaannya. Sosialisasi pada BPKP Perwakilan Provinsi DKI Jakarta dilakukan hanya dua kali, namun sosialisasi yang hanya dua kali tersebut langsung bisa dipahami oleh pegawai. Hasil wawancara pada level user atau pengguna pun menyebutkan hasil yang senada bahwa aplikasi ST atau SKI mudah digunakan.

Aplikasi ST atau SKI jarang mengalami gangguan pada sistemnya. Lama respon dan waktu loading pun termasuk cepat. Peneliti sempat mencoba langsung untuk $\log$ in menggunakan aplikasi ST atau SKI. Hasil percobaan menunjukkan bahwa respon time dari aplikasi ini cenderung cepat. Sedangkan dari hasil wawancara dengan pengguna menyatakan bahwa aplikasi ST atau SKI cepat terbuka dan tidak perlu menunggu waktu yang lama ketika diakses, baik dengan mengunakan internet kantor (wifi) atau internet pribadi (modem pribadi). Hal yang dirasakan tidak efisien oleh pengguna adalah ketika melakukan input nama-nama dalam pembuatan surat tugas. Ketika terjadi kesalahan input baik nama maupun jabatan, pengguna harus mengulangnya dari awal (input nama), tidak bisa dilakukan perbaikan pada nama-nama yang sudah terlanjur diinput.

Aplikasi ST atau SKI masih mengalami kesulitan dalam berintegrasi dengan aplikasi lain. Integrasi yang bisa dilakukan hanyalah perpindahan atau migrasi dalam bentuk database dari aplikasi ST atau SKI ke aplikasi lain yang membutuhkan, misalnya dengan aplikasi Integrated Performance Management System (IPMS). IPMS adalah aplikasi milik BPKP yang digunakan untuk merencanakan dan memanajemen kinerja organisasi. Selain itu, berkaitan dengan kehandalan sistem, aplikasi ST atau SKI memberikan fitur peringatan dalam bentuk warna-warna yang berbeda maksudnya. Misalnya dalam pembuatan surat tugas, pada kolom eselon 4, eselon 3, eselon 2, maupun eselon 1 akan berwarna merah ketika belum mendapat persetujuan. Warna tersebut akan berubah menjadi hijau ketika eselon yang bersangkutan telah memberikan persetujuan. Warna-warna ini tidak bisa dimanipulasi karena setiap pejabat eselon diberikan username dan password masingmasing untuk menjamin keamanan sistem.

Ketika jangka waktu pelaksanaan surat tugas telah selesai, maka aplikasi akan secara otomatis menghitung lama waktu untuk melakukan upload atas output dari surat tugas yang ditunjukkan dengan warna-warna yang berbeda pada baris surat tugas tersebut. Warna biru muda menunjukkan bahwa output diselesaikan lebih awal, maka baris realisasi output akan berwarna biru muda. Warna putih menunjukkan bahwa output diselesaikan masih dalam jangka waktu penyelesaian. Warna kuning menunjukkan bahwa output telah melewati batas waktu penyelesaian (deadline). Sedangkan warna merah menunjukkan bahwa output telah terlambat lebih dari 15 hari kerja.

\section{Kualitas informasi (information quality).}

Faktor ini digunakan untuk mengukur kualitas keluaran (output) dari sistem informasi. Beberapa indikator yang pernah diteliti Yusof et al. (2006) dan Yusof et al. (2008) untuk mengukur nilai dari kualitas informasi output adalah Indikator isi (content) yang meliputi format sesuai kebutuhan, bentuk serta relevansi dari informasi yang dihasilkan, dan kelengkapan (completeness); Indikator kegunaan (usefulness) yang meliputi mudah dibaca, ringkas dan padat, dan informatif; dan Tingkat kehandalan data yang meliputi akurasi data, ketepat waktuan, dapat dibandingkan dan dapat diverifikasi.

Aplikasi ST atau SKI secara garis besar digunakan untuk menyusun pembuatan SKP dan melakukan input realisasi SKP berdasarkan surat tugas. Pengguna tidak memiliki keluhan terkait format, bentuk dan relevansi dari format penilaian SKP yang dicetak dari aplikasi. Pada penggunaan yang lain yaitu pembuatan surat tugas, beberapa responden mengeluhkan format 
yang masih kurang memuaskan. Tata letak kalimat dalam surat tugas dinilai kurang rapi, misalnya ketika menulis tanggal 05 Februari 2016. Pergantian baris bisa dimanapun tergantung kecukupan kata pada satu baris, bisa setelah angka "05" atau setelah kata "Februari". Hal ini dinilai tidak rapi dan tidak bisa diatasi secara otomatis pada aplikasi. Selain itu pengguna juga mengeluhkan kelengkapan surat tugas yang tidak diakomodasi oleh aplikasi. Aplikasi ST atau SKI hanya mengakomodasi pembuatan Surat Tugas (ST) padahal sebuah ST seringkali tidak bisa berdiri sendiri, perlu adanya kelengkapan lain, misalnya surat pengantar, rencana hari penugasan, dan rencana biaya. Keluhan lain ketika melakukan input realisasi surat tugas pada kolom "Kualitas Output" dalam bentuk persentase. Salah satu responden yang berperan sebagai Pengendali Teknis (Dalnis) mengaku belum paham terkait kualitas yang dimaksud, bagaimana cara menentukan persentasenya, dan siapa yang berhak mengisi. Pada praktiknya, kolom tersebut cenderung diisi $100 \%$.

Semua responden yang setuju bahwa informasi yang dihasilkan oleh aplikasi ST atau SKI mudah dibaca dan dipahami. Format SKP dan format ST yang dicetak menggunakan aplikasi sesuai dengan kebutuhan, mudah dibaca dan dipahami. Salah satu fungsi dari aplikasi ST atau SKI adalah menyeragamkan format SKP dan format pembuatan ST. Sehingga, dari sisi informasi yang dihasilkan output tersebut dapat dibandingkan antara satu pegawai dengan pegawai yang lain dan dapat diverifikasi oleh pejabat penilai SKP.

\section{Kualitas pelayanan (service quality).}

Kualitas layanan berfokus pada keseluruhan dukungan yang diterima dari penyedia jasa layanan sistem. Kualitas layanan dapat dinilai dengan kecepatan respon, jaminan, empati, dukungan teknis dan tindak lanjut layanan kepada pengguna sistem.
Semua responden baik pimpinan, admin, maupun user berpendapat bahwa aplikasi ST atau SKI jarang mengalami gangguan. Apabila terjadi gangguan biasanya disebabkan oleh masalah jaringan internet, bukan dari aplikasi itu sendiri. Masalah yang berkaitan dengan jaringan internet dapat diatasi sendiri oleh BPKP Perwakilan tanpa perlu melibatkan BPKP Pusat. Apabila aplikasi ST atau SKI yang mengalami masalah, yang sangat jarang terjadi, BPKP Perwakilan perlu meminta bantuan dari tim IT pada Pusinfowas BPKP Pusat selaku unit yang mengembangkan aplikasi ST atau SKI. Admin aplikasi ST atau SKI pada BPKP Perwakilan DKI Jakarta mengatakan bahwa tim IT dari Pusinfowas sangat bagus dan cepat dalam bekerja. Terlihat terlatih dan cukup menguasai aplikasi ST atau SKI. Respon dari tim IT Pusinfowas BPKP juga cepat ketika menerima pengaduan gangguan sistem dari BPKP Perwakilan DKI Jakarta.

\section{Tabel 3}

\section{Resume Elemen Teknologi dari Evaluasi ST atau SKI}

\begin{tabular}{|c|c|}
\hline Dimensi & Temuan \\
\hline Kualitas Sistem & $\begin{array}{l}\text { ST atau SKI mudah di- } \\
\text { gunakan dan mudah di- } \\
\text { pelajari. Respon dan lama } \\
\text { loading pada aplikasi cende- } \\
\text { rung cepat. ST atau SKI } \\
\text { belum terintegrasi dengan } \\
\text { sistem lain. Terdapat fitur } \\
\text { peringatan kesalahan pada } \\
\text { aplikasi. }\end{array}$ \\
\hline $\begin{array}{l}\text { Kualitas } \\
\text { Informasi }\end{array}$ & $\begin{array}{l}\text { Format, bentuk dan rele- } \\
\text { vansi dari format penilaian } \\
\text { SKP sudah sesuai kebutu- } \\
\text { han. Format dan keleng- } \\
\text { kapan ST masih perlu per- } \\
\text { baikan. Informasi yang di- } \\
\text { hasilkan ST atau SKI mu- } \\
\text { dah dibaca dan dipahami. }\end{array}$ \\
\hline $\begin{array}{l}\text { Kualitas } \\
\text { Layanan }\end{array}$ & $\begin{array}{l}\text { Respon tim IT atas keluhan } \\
\text { user cenderung cepat. } \\
\text { Tim IT yang bagus dan } \\
\text { menguasai bidangnya. }\end{array}$ \\
\hline
\end{tabular}

Sumber: data yang diolah peneliti 


\section{Manfaat (net benefit)}

Net benefit merupakan manfaat yang diperoleh dari penggunaan sistem. Net benefits dapat diukur dari manfaat sistem secara langsung pada individu pegawai (misalnya dari informasi yang dihasilkan sistem). Penilaian net benefit pada individu pegawai dapat dilakukan dengan mempertimbangkan job effects, efisiensi, efektivitas dan error reduction. Manfaat lain pada net benefit dapat dinilai secara tidak langsung seperti dampak pada kinerja, efisiensi dan efektifitas kegiatan organisasi.

Sebanyak $77 \%$ responden mengatakan bahwa aplikasi ST atau SKI dapat membantu mengerjakan tugas yang berkaitan dengan pengukuran kinerja pegawai. Sedangkan $72 \%$ dari responden yang sama mengatakan bahwa aplikasi ST atau SKI membantu meningkatkan efisiensi pekerjaan. Penyusunan SKP pada awal tahun dapat dilakukan secara sistem dengan format yang telah diseragamkan. Begitu juga dengan pembuatan surat tugas dan penyusunan realisasi SKP pada akhir tahun telah dilakukan secara otomatisasi oleh sistem. Hal ini dapat meminimalisasi error seperti misalnya format penilaian SKP yang salah atau typo pada surat tugas.

Dampak tidak langsung aplikasi ST atau SKI yang berhubungan dengan organisasi dapat dilihat pada pengaruh aplikasi terhadap kinerja, efisiensi dan efektivitas kegiatan organisasi. Aplikasi ST atau SKI memiliki sedikit pengaruh terhadap kinerja organisasi terutama dalam hal pengambilan keputusan. Pengambilan keputusan dimaksud berkenaan dengan pegawai yang akan mendapat penugasan berikutnya. Aplikasi ST atau SKI dapat memberikan gambaran secara helicopter view kepada pimpinan atau atasan. Pimpinan atau atasan dapat memantau berapa banyak realisasi yang telah dikerjakan anak buahnya sekaligus dapat melihat berapa banyak pegawai atau tim yang terlambat mengumpulkan hasil output dari surat tugas. Fasilitas dapat dijadikan sebagai salah satu dasar pertimbangan untuk melakukan penugasan berikutnya.
Misalnya, pegawai atau tim yang masih banyak menunggak output laporan untuk sementara tidak diberikan penugasan lebih lanjut. Peran dalam hal pengambilan keputusan pada aplikasi ini belum berfungsi maksimal karena berdasarkan keterangan responden tidak ada perbedaan perlakuan antara pegawai yang tertib melakukan input realisasi Surat Tugas (ST) dengan pegawai yang sering terlambat melakukan input realisasi. Hal ini berpengaruh pada keengganan pegawai untuk tertib melakukan input realisasi ST walaupun sebenarnya output dari ST telah terselesaikan, sehingga apa yang ditampilkan pada aplikasi tidak mencerminkan realita yang sebenarnya. Menurut keterangan responden sanksi yang tidak tegas menjadi alasan sebagian besar pegawai untuk tidak tertib dalam menggunakan aplikasi ST atau SKI.

\section{Kesesuaian antara Manusia, Organisasi dan Teknologi}

Pada framework Hot-fit Model, kesesuaian antara ketiga elemen difokuskan pada kemampuan antara elemen manusia, teknologi, dan organisasi untuk bisa saling menyesuaikan satu sama lain. Jadi, kesesuaian (fit) ini dapat diukur dan dianalisis dari beberapa kompatibilitas yang terlihat antara tiga elemen di atas (Yusof, 2008).

\section{Kesesuaian antara Manusia dan Organi- sasi}

Kesesuaian pertama dilihat dari hubungan antara dimensi manusia dan organisasi (fit between human and organization). Kesesuaian (fit) yang dapat dilihat antara manusia dan organisasi adalah adanya hubungan baik antara pengguna dan pimpinan organisasi di lingkungan kantor BPKP Perwakilan DKI Jakarta. Seringnya himbauan dari Kasubag Prolap sebagai penanggung jawab aplikasi serta kepedulian dari Kepala Perwakilan terhadap aplikasi menunjukkan adanya hubungan yang bagus dalam pemanfaatan aplikasi ST atau SKI. Hal ini akan berdampak pada adanya kolaborasi yang bagus secara kerja sama 
organisasi untuk menyukseskan penggunaan aplikasi serta secara keseluruhan aplikasi dapat dijalankan dengan baik.

Kesesuaian (fit) berikutnya adalah adanya dukungan dari Kepala Perwakilan sebagai pengambil keputusan tertinggi pada BPKP Perwakilan Provinsi DKI Jakarta. Dukungan dimaksud berupa penolakan dari Kepala Perwakilan untuk menandatangani dokumen yang seharusnya dicetak melalui aplikasi namun masih dicetak secara manual. Dukungan ini penting sebagai bentuk dorongan agar pegawai pada level dibawahnya turut menggunakan aplikasi ini. Selain adanya kesesuaian (fit) dari hasil penelitian ditemukan pula adanya ketidak sesuaian (misfit) antara manusia dan organisasi. Ketidaksesuaian (misfit) yang terjadi adalah adanya sebagian pegawai yang tidak komitmen dalam memanfaatkan aplikasi. Sebagian pegawai cenderung menggunakan aplikasi hanya sebatas pada fitur yang memang harus menggunakan aplikasi, misalnya pembuatan surat tugas. Output dari surat tugas yang seharusnya diunggah pada aplikasi sebagai kontrol dari manajemen seringkali diabaikan karena tidak adanya sanksi tegas dari organisasi. Hal ini akan berdampak pada menurunnya manfaat aplikasi yang dirasakan oleh organisasi. Organisasi tidak bisa mengambil manfaat dari aplikasi ini secara maksimal.

\section{Kesesuaian antara Manusia dan Teknologi}

Kesesuaian kedua dilihat dari hubungan antara dimensi manusia dan teknologi (fit between human and technology). Kesesuaian (fit) yang dapat dilihat adalah cakapnya tenaga IT dari Pusinfowas ketika timbul masalah pada aplikasi ST atau SKI. Hal ini akan berdampak pada kepuasan pengguna dalam pemanfaatan aplikasi sehingga dapat mendorong pegawai untuk tertib dalam menggunakan aplikasi ST atau SKI.

Kesesuaian (fit) berikutnya adalah terus dilakukan pengembangan terhadap aplikasi ini sesuai masukan dan keluhan pengguna. Pengembangan masih terus dilakukan dengan menambah fitur-fitur yang diang- gap bermanfaat. Hal ini akan berdampak pada meningkatnya jumlah pegawai yang menggunakan aplikasi ini serta meningkatnya kepuasan pengguna yang memanfaatkan aplikasi ST atau SKI.

Selain adanya kesesuaian (fit) dari hasil penelitian ditemukan pula adanya ketidak sesuaian (misfit) antara manusia dan teknologi. Ketidaksesuaian (misfit) yang ditemuan adalah kepatuhan dari pegawai untuk tertib menggunakan aplikasi ST atau SKI masih kurang. Kepatuhan yang dimaksud terutama dalam hal ketertiban pegawai memperhatikan deadline untuk menyelesaikan output surat tugas dan mengunggahnya dalam aplikasi. Ketidaktertiban ini akan membuat kualitas informasi dalam hal akurasi data pada aplikasi ST atau SKI menjadi berkurang.

\section{Kesesuaian antara Organisasi dan Tekno- logi}

Kesesuaian ketiga dilihat dari hubungan antara dimensi organisasi dan teknologi (fit between organization and technology). Kesesuaian (fit) yang dapat dilihat adalah BPKP DKI Jakarta menyediakan fasilitas dan infrastruktur yang dapat digunakan untuk menjalankan aplikasi ST atau SKI. Sebagian besar pegawai menggunakan internet (wifi) kantor untuk mengakses aplikasi. Setiap bidang disediakan perangkat komputer untuk menunjang kegiatan sehari-hari. Hal ini berdampak pada minimnya kendala teknis dalam pemanfaatan aplikasi ST atau SKI.

Selain adanya kesesuaian (fit) seperti yang telah dijelaskan pada paragraf di atas, dari hasil penelitian ditemukan pula adanya ketidaksesuaian (misfit) antara organisasi dan teknologi. Ketidaksesuaian (misfit) tersebut adalah tidak adanya aturan yang memberikan sanksi bagi pegawai yang tidak tertib menggunakan aplikasi. Hal ini dapat berdampak pada tidak maksimalnya manfaat yang diperoleh organisasi dari aplikasi ST atau SKI. Resume kesesuaian antara elemen manusia, organisasi, dan teknologi ditampilkan pada Tabel 4. 


\section{Tabel 4}

Kesesuaian (Fit) antara Elemen Manusia, Organisasi, dan Teknologi

\begin{tabular}{|c|c|c|}
\hline Elemen & $\begin{array}{l}\text { Kesesuaian } \\
\text { (fit) }\end{array}$ & Dampak \\
\hline \multirow{2}{*}{$\begin{array}{l}\text { Manusia } \\
\text { dan } \\
\text { Organisasi }\end{array}$} & $\begin{array}{l}\text { Hubungan baik } \\
\text { antara user dan } \\
\text { pimpinan orga- } \\
\text { nisasi }\end{array}$ & $\begin{array}{l}\text { Kolaborasi dan } \\
\text { kerja sama } \\
\text { yang bagus un- } \\
\text { tuk menyuk- } \\
\text { seskan peng- } \\
\text { gunaan apli- } \\
\text { kasi }\end{array}$ \\
\hline & $\begin{array}{l}\text { Dukungan dari } \\
\text { top manajemen }\end{array}$ & $\begin{array}{l}\text { Dorongan agar } \\
\text { pegawai pada } \\
\text { level bawah } \\
\text { turut meng- } \\
\text { gunakan apli- } \\
\text { kasi }\end{array}$ \\
\hline \multirow{2}{*}{$\begin{array}{l}\text { Manusia } \\
\text { dan } \\
\text { Teknologi }\end{array}$} & $\begin{array}{l}\text { Tenaga IT } \\
\text { cukup cakap }\end{array}$ & $\begin{array}{l}\text { Kepuasan pe- } \\
\text { ngguna dalam } \\
\text { menggunakan } \\
\text { aplikasi }\end{array}$ \\
\hline & $\begin{array}{l}\text { Kontinuitas } \\
\text { pengembangan } \\
\text { aplikasi }\end{array}$ & $\begin{array}{l}\text { Peningkatan } \\
\text { jumlah pega- } \\
\text { wai dalam pe- } \\
\text { nggunaan } \\
\text { aplikasi }\end{array}$ \\
\hline $\begin{array}{l}\text { Organisasi } \\
\text { dan } \\
\text { Teknologi }\end{array}$ & $\begin{array}{l}\text { Penyediaan } \\
\text { fasilitas dan } \\
\text { infrastruktur } \\
\text { pendukung }\end{array}$ & $\begin{array}{l}\text { Minimalisasi } \\
\text { kendala teknis }\end{array}$ \\
\hline
\end{tabular}

Sumber: data yang diolah peneliti

Sedangkan Tabel 5 menunjukkan resume ketidakkesesuaian antara elemen manusia, organisasi, dan teknologi.

\section{Tabel 5}

Ketidaksesuaian (Misfit) Antara Elemen Manusia, Organisasi, dan Teknologi

\begin{tabular}{|c|c|c|}
\hline Elemen & $\begin{array}{l}\text { Ketidaksesuaian } \\
\text { (misfit) }\end{array}$ & Dampak \\
\hline $\begin{array}{l}\text { Manusia } \\
\text { dan } \\
\text { Organisasi }\end{array}$ & $\begin{array}{l}\text { Pegawai tidak } \\
\text { komitmen } \\
\text { menggunakan } \\
\text { aplikasi }\end{array}$ & $\begin{array}{l}\text { Menurunnya } \\
\text { manfaat apli- } \\
\text { kasi yang di- } \\
\text { rasakan } \\
\text { organisasi } \\
\end{array}$ \\
\hline $\begin{array}{l}\text { Manusia } \\
\text { dan } \\
\text { Teknologi }\end{array}$ & $\begin{array}{l}\text { Kurangnya } \\
\text { kepatuhan } \\
\text { pegawai untuk } \\
\text { tertib }\end{array}$ & $\begin{array}{l}\text { Akurasi data } \\
\text { pada apli- } \\
\text { kasi menjadi } \\
\text { berkurang }\end{array}$ \\
\hline
\end{tabular}

\begin{tabular}{lll}
\hline \multicolumn{3}{l}{$\begin{array}{l}\text { menggunakan } \\
\text { aplikasi. }\end{array}$} \\
\hline $\begin{array}{l}\text { Organisasi } \\
\text { dan }\end{array}$ & Tidak ada sanksi & Manfaat dari \\
tegas bnologi & pegawai & $\begin{array}{l}\text { aplikasi ter- } \\
\text { hadap orga- } \\
\text { nisasi tidak } \\
\end{array}$ \\
& & maksimal \\
\hline
\end{tabular}

Sumber: data yang diolah peneliti

\section{SIMPULAN DAN SARAN Simpulan}

Berdasarkan hasil penelitian evaluasi aplikasi ST atau SKI pada instansi BPKP, studi kasus pada BPKP Perwakilan Provinsi DKI Jakarta menggunakan framework HOTFit Model, diketahui bahwa penerapan aplikasi ST atau SKI pada BPKP Perwakilan Provinsi DKI Jakarta secara umum telah sesuai dengan framework HOT-Fit Model, meskipun dalam beberapa elemen masih terdapat kekurangan. Pada elemen manusia, semua responden sepakat bahwa aplikasi ST atau SKI perlu dipertahankan. Sebanyak $90 \%$ dari responden yang sama menginginkan ada penambahan fitur untuk membantu penyusunan angka kredit bagi pegawai fungsional. Tampilan ST atau SKI yang sederhana dan mudah dipahami memungkinkan aplikasi ini mampu digunakan oleh pegawai dari berbagai kalangan umur, baik yang menguasai komputer dengan baik maupun yang menguasai komputer ala kadarnya.

Sedangkan pada elemen organisasi, kepedulian dan perhatian dari pimpinan baik di level BPKP Perwakilan maupun di level BPKP Pusat merupakan indikasi yang bagus dalam pemanfaatan aplikasi ST atau SKI. Namun kepedulian yang diwujudkan dengan himbauan untuk menggunakan aplikasi dengan lebih tertib perlu rasanya ditindaklanjuti dengan dibuatnya peraturan terkait penggunaan aplikasi, termasuk adanya sanksi terhadap pegawai yang tidak menggunakan apikasi ST atau SKI dengan tertib. Hal ini mengingat ST atau SKI merupakan perwujudan dari PP Nomor 46 Tahun 2011 tentang Penilaian Prestasi Kerja Pegawai Negeri Sipil, yang diwajibkan 
dilakukan pada seluruh PNS di instansi pemerintah termasuk pada PNS BPKP. Terkait dengan elemen teknologi, sebanyak 95\% responden yang menyatakan bahwa aplikasi ST atau SKI mudah digunakan dan mudah dipelajari. Selain itu dari keterangan responden menyatakan bahwa aplikasi ST atau SKI jarang mengalami gangguan. Gangguan yang terjadi pun seringnya bukan berkaitan dengan aplikasi itu sendiri namun lebih disebabkan gangguan pada layanan internet. Kekurangan dari segi teknologi diantaranya adalah kesulitan untuk dapat berintegrasi dengan aplikasi lain.

Pada pembahasan net benefit, sebanyak $77 \%$ responden menyatakan setuju jika aplikasi ST atau SKI dapat membantu pegawai mengerjakan tugas yang berkaitan dengan pengukuran kinerja pegawai. Sedangkan sebanyak $72 \%$ dari responden yang sama mengatakan bahwa aplikasi ST atau SKI membantu meningkatkan efisiensi pekerjaan. Berdasarkan ringkasan hasil evaluasi aplikasi ST atau SKI menggunakan framework HOT-Fit Model, aplikasi ST atau SKI telah memenuhi standar sistem yang sesuai berdasarkan elemen-elemen dan dimensi-dimensi yang dipersyaratkan dalam frame-work HOT-Fit Model.

Kekurangan-kekurangan yang timbul yang menyebabkan aplikasi ini belum mampu bekerja maksimal untuk mengakomodasi kepentingan organisasi seperti misalnya dalam hal pengambilan keputusan, memudahkan pejabat penilai (atasan langsung) untuk memantau kegiatan masingmasing pegawai yang dinilai, dan memudahkan unit kepegawaian untuk mendata pegawai-pegawai yang sudah maupun belum mengajukan SKP, banyak disebabkan oleh elemen organization (organisasi). Hal ini terlihat dari elemen organisasi yang paling banyak muncul pada pembahasan ketidak sesuaian (misfit) yang dijabarkan pada Bab IV. Salah satu penyebabnya belum ada peraturan yang secara tegas memberikan sanksi kepada pegawai yang tidak tertib menggunakan aplikasi. Usaha yang dilaku- kan masih sebatas himbauan. Dari keterangan responden, pegawai yang tidak tertib menggunakan aplikasi tidak memiliki efek apa-apa dari sisi kelangsungan pekerjaan. Pegawai tersebut masih bisa mendapatkan penugasan selanjutnya walaupun secara sistem dia terlihat masih menunggak realisasi atas kegiatan yang sudah dilaksanakan.

\section{Saran}

Berdasarkan penelitian ini, hal-hal yang dapat dilakukan untuk meningkatkan aplikasi ST atau SKI adalah tim pengembang aplikasi perlu menambah fitur alert (peringatan) atau banned temporary kepada pegawai yang melewati batas minimal keterlambatan mengunggah output surat tugas (elemen technology) dan segenap jajaran struktur organisasi perlu berperan secara aktif untuk melakukan pendekatan persuasif agar pegawai tertib menggunakan aplikasi ST atau SKI (elemen organization).

Penelitian ini hanya dilakukan di BPKP Perwakilan Jakarta sehingga hasil penelitian ini tidak bisa digeneralisir di seluruh kantor BPKP. Untuk melihat implementasi aplikasi ST atau SKI di BPKP secara keseluruhan, diperlukan penelitian yang lebih komprehensif di BPKP Pusat dan Perwakilan. Selain itu, penelitian ini hanya berfokus pada tiga aspek terkait dengan penerapan aplikasi, yaitu manusia, organisasi dan teknologi sehingga diperlukan aspek atau faktor lain untuk melihat tantangan dan kendala penerapan aplikasi ST atau SKI sehingga bisa didapatkan solusi penerapan aplikasi yang lebih efektif dan efisien. Faktor lain yang perlu dianalisis lebih lanjut terkait evaluasi aplikasi ini diantaranya seperti karakteristik pekerjaan, relevansi pekerjaan, pengalaman kerja, dan karakteristik demografi pengguna.

\section{DAFTAR PUSTAKA}

Amarullah, Krizna Dwiyan. 2016. Evaluasi Penerapan Sistem Aplikasi Pengaduan Masyarakat (Sipuma) Direktorat Jenderal Bea dan Cukai. Tangerang Selatan: Politeknik Keuangan Negara STAN. 
Arikunto, S dan Abdul Jabar, Cepi Safrudin. 2008. Evaluasi Program Pendidikan. PT Bumi Aksara. Jakarta.

Chariri, A. 2009. Landasan filsafat dan metode penelitian kualitatif.

Creswell, John W. 2015. Research Design Pendekatan Kualitatif, Kuantitatif, dan Mixed. Pustaka Pelajar. Yogyakarta.

DeLone, W. H., \& McLean, E. R. 2003. The DeLone and McLean model of information systems success: a ten-year update. Journal of management information systems 19(4): 9-30.

Jogiyanto, HM. 2005. Analisis dan Desain Sistem Informasi: Pendekatan Terstruktur Teori dan Praktik Aplikasi Bisnis. Andi. Yogyakarta.

Kusumawati, Ayu Meirani dan Eva Hany Fanida. 2014. Evaluasi Sistem Aplikasi Pelayanan Kepegawaian (SAPK) melalui "Hot-Fit" Model di Kantor Regional II Badan Kepegawaian Negara Surabaya. Publika Unesa 2(1).

Laudon, Kenneth C. dan Jane P. Laudon. 2001. Essentials of Management Information Systems: Organization and Technology in The Networked Enterprise, edisi ke-4. Upper Saddle River, New Jersey: Prentice-hall, Inc.

McLeod, Raymond, Jr. dan George Schell. 2011. Management Information System: Edisi Bahasa Indonesia, edisi ke-10. Salemba Empat. Jakarta.

O'Brien, James A. dan George M. Marakas. 2009. Management Information Systems, edisi ke-9. New York: McGraw-Hill Companies Inc.
Petter, S., DeLone, W., \& McLean, E. 2008. Measuring information systems success: models, dimensions, measures, and interrelationships. European journal of information systems 17(3): 236-263.

Sugiyono, P. 2010. Memahami Penelitian Kualitatif. Bandung: Alfabeta.

Sugiyono, P. 2015. Metode penelitian kombinasi (mixed methods). Alfabeta. Bandung.

Yusof, M. M., R. J. Paul dan L. K. Stergioulas. 2006. Towards a Framework for Health Information Systems Evaluation. Proceedings of the 39th Hawaii International Conference on System Sciences - 20060-7695-2507-5/06/\$20.00 (C) 2006 IEEE.

Yusof, M. M., Kuljis, J., Papazafeiropoulou, A., dan Stergioulas, L. K. 2008. An evaluation framework for Health Information Systems: human, organization and technology-fit factors (HOT-fit). International journal of medical informatics 77(6): 386-398.

Yusof, M. M. 2011. Hot-Fit Evaluation Framework: Validation Using Case Studies and Qualitative Systemic Review in Health Information Systems Evaluation Adoption. Proceedings of 5 th Europe Conference on Information Management and Evaluation, 8-9 September, Como: Italy.

Yusof, M. M., \& Yusuff, A. Y. A. 2013. Evaluating E-government system effectiveness using an integrated sociotechnical and fit approach. Information Technology Journal 12(5): 894. 